\title{
A Novel Approach for Optimization of Crude Oil Bioremediation in Soil by the Taguchi Method
}

\author{
Seyed Foad Aghamiri ${ }^{1}$, Kasra Kabiri ${ }^{1}$ and Giti Emtiazi ${ }^{2 *}$
}

${ }^{1}$ Chemical Engineering Dept., University of Isfahan, Isfahan, Iran, 81746-73441

${ }^{2}$ Biological Science Dept., University of Isfahan, Isfahan, Iran, 81746-73441

\begin{abstract}
A design of experiment technique, the Taguchi method, has been used to optimize bioremediation of crude oil in contaminated soils. Mixed cultures of three strains of bacteria were used. Two sets of experiments were conducted with 8 factors in each set. In the first set of experiments the factors were aeration, bacteria, urea, glucose, humidity, compost, salt, and temperature. In the second set of experiments aeration and temperature were replaced with time and activated sludge, also molasses was used as additional carbon source. The contribution percentage of each factor was determined by analysis of variance. The oil removal was $64.4 \%$ and $68 \%$ for optimum conditions of the first and second set of experiments, respectively. Addition of urea and molasses showed low effect on oil removal, whereas aeration revealed $98 \%$ of oil removal from the contaminated soil. Also addition of activated sludge and compost did not substitute for mix culture of Pseudomonas.
\end{abstract}

Keywords: Bioremediation; Taguchi method; Bacteria; Crude oil; Soil population

\section{Introduction}

World crude oil production is about 86 million barrels/day and estimated rich to 118 million barrels/day until 2030 [1]. It is estimated about $0.1 \%$ of the global produced oil is emanated, through up streams and down streams processes $[2,3]$.

During the accidental spills, action will be taken to remove or remediate or recover the contaminant immediately [4]. The need to remediate the contaminated site has led to develop a wide variety of innovative chemical, physical and biological processes that eliminate hazardous organics from the environment without causing further ecological damages. Public concern towards the conservation of the environment demands for new and more environmentally efficient low cost strategies for cleanup contaminated sites [5]. A number of physical, chemical and biological methods have been developed for remediate the oil contamination [6]. Although each of these methods has its advantage and drawbacks, the biological processes such as bioremediation has become a valuable alternative to chemical and physical (traditional) methods. Bioremediation has low operation cost and can remove small amount of contaminations that usually will be remained after applying a traditional method. Also, these biological processes are simpler than traditional methods and can be employed without huge transport of chemicals to contaminated sites. Three important disadvantages of the traditional methods are harsh side effects, high costs and are inconvenient application [7]. Bioremediation can be defined as any process that uses microorganisms, green plants or their enzymes to return the environment altered by contaminants to its original condition [8]. Biodegradation of pollutants using the plants (i.e. phytoremediation) and their associated microorganisms has been shown to be effective for remediation of oil contaminated soils [9$13,21,22,27]$.

Biodegradation of petroleum hydrocarbons in soil could be limited by physico-chemical factors (e.g. nutrient, $\mathrm{pH}$, temperature, oxygen) as well as biological factors ( e.g. number and species of indigenous microbes, biosurfactant, seeding) [9]. Besides, the mentioned factors could affect on the rate of uptake and mineralization of organic compounds in contaminated sites [10]. Temperature plays a significant role in controlling the nature and extent of microbial hydrocarbon metabolism [10]. Hence, temperature affects on the rate of biodegradation, as well as the physical and chemical composition of hydrocarbon [11]. Degradation of soil hydrocarbons could be increased by addition of supplemental nutrients, particularly nitrogen and to a lesser degree phosphorus [5]. Biodegradation of complex hydrocarbons usually requires the cooperation of more than a single microbial species. This is particularly true in the case of complete mineralization of pollutant (e.g. crude oil) including various compounds [12]. Bioremediation has been used on very large scale application, as demonstrated by the shore-line clean-up efforts in Prince William Sound, Alaska after the Exxon Valdez oil spill, most extensive use of bioremediation technique, there have been much other successful applications on smaller scale $[3,13]$.

In this study, a design of experiment (DOE) technique based on the Taguchi method has been implemented to optimize bioremediation of crude oil in contaminated soils. In this process experiments are designed and carried out by using a set of orthogonal arrays. By using this method, the number of required experiments is significantly reduced to investigate an objective function when there are a number of variables $[14,15]$. This method has capability to predict the optimized conditions and optimum results. The Taguchi method has been used as a statistical tool for biotechnological application in several researches $[2,12,26]$. Besides, the contribution percentage of each factor (effective percent) is determined by the analysis of variance (ANOVA).

*Corresponding author: Dr. Giti Emtiazi, Biological Science Dept, University of Isfahan, Isfahan, Iran, 81746-73441, E-mail: emtiazi@yahoo.com

Received January 17, 2011; Accepted April 24, 2011; Published April 28, 2011

Citation: Aghamiri SF, Kabiri K, Emtiazi G (2011) A Novel Approach for Optimization of Crude Oil Bioremediation in Soil by the Taguchi Method. J Pet Environ Biotechnol 2:110. doi:10.4172/2157-7463.1000110

Copyright: (c) 2011 Aghamiri SF, et al. This is an open-access article distributed under the terms of the Creative Commons Attribution License, which permits unrestricted use, distribution, and reproduction in any medium, provided the original author and source are credited. 


\section{Materials and Methods}

\section{Chemicals}

Carbon tetrachloride, glucose, urea, sodium chloride, magnesium sulfate, nutrient agar, and nutrient broth were obtained from Merck Company, Germany.

\section{Soil}

Soil samples were collected from around of the Isfahan refinery, Iran. Samples were homogenized, passed through a sieve No. 16 (Obtained from Sehpahan Danesh) and stored at room temperature. The sieve pore was $1 \mathrm{~mm}$ for mesh 16 with nominal wire diameter 0.580 $\mathrm{mm}$. Therefore, the particles of used soil had diameter less than $1 \mathrm{~mm}$.

\section{Crude oil}

The crude oil obtained from the Isfahan refinery, Iran. The main properties of soil and crude oil have been shown in Table 1 .

\section{Bacteria}

In this study, three Gram negative strains of bacteria were selected to accelerate the bioremediation of the contaminated soil. These strains have been isolated from Isfahan refinery and Ahwaz oil field and applied for biodegradation of crude petroleum oil [16]. They were recognized as Pseudomonas by microbial identification tests. The identification was approved by Institute of Razi, according to $16 \mathrm{~s}$ RNA.

\section{Mineral based media}

A solution of $1 \mathrm{~g}\left(\mathrm{NH}_{4}\right)_{2} \mathrm{SO}_{4}, 1 \mathrm{~g} \mathrm{KH}_{2} \mathrm{PO}_{4}$ and $1 \mathrm{~g} \mathrm{~K}_{2} \mathrm{HPO}_{4}$ in 1000 $\mathrm{ml}$ distilled water was prepared. This solution was autoclaved at $121^{\circ} \mathrm{C}$ for 15 minutes. Then $0.004 \mathrm{~g} \mathrm{FeCl}_{3}$ and $0.04 \mathrm{~g} \mathrm{MgSO}_{4}$ were added to the solution. After that $0.2 \mathrm{ml}$ crude oil was added to a $100 \mathrm{ml}$ solution

\begin{tabular}{|c|c|c|}
\hline & Specification & Value \\
\hline & Clay (\%) & 12 \\
\hline & Silt $(\%)$ & 8 \\
\hline & Sand $(\%)$ & 80 \\
\hline \multirow[t]{12}{*}{ Soil } & $\mathrm{pH}$ & 7.3 \\
\hline & Nitrogen (\%) & 0.41 \\
\hline & Available P (ppm) & 15 \\
\hline & Available K (ppm) & 180 \\
\hline & Texture & LS \\
\hline & Particle Size (m) & $<0.001$ \\
\hline & Soil microbial population (CFU/g) & $1.9 \times 10^{7}$ \\
\hline & Sp. Gr. at $15^{\circ} \mathrm{C} / 15^{\circ} \mathrm{C}$ & 0.8575 \\
\hline & Kinematics viscosity at $10^{\circ} \mathrm{C}$ (c.st) & 18.09 \\
\hline & Kinematics viscosity at $20^{\circ} \mathrm{C}$ (c.st) & 11.93 \\
\hline & Kinematics viscosity at $40^{\circ} \mathrm{C}$ (c.st) & 6.28 \\
\hline & Water and Sediments (vol. \%) & 0.5 \\
\hline \multirow[t]{10}{*}{ Petroleum oil } & $\mathrm{H}_{2} \mathrm{~S}(\mathrm{ppm})$ & Trace \\
\hline & Sulfur content (wt. \%) & 1.3 \\
\hline & Asphaltene (wt. \%) & 2.0 \\
\hline & Nitrogen total (wt. \%) & 0.17 \\
\hline & Carbon residue (wt. \%) & 3.61 \\
\hline & Wax content (wt. \%) & 11.0 \\
\hline & Nickel (ppm) & 1.22 \\
\hline & Vanadium (ppm) & 7.1 \\
\hline & Iron (ppm) & 21.7 \\
\hline & Sodium (ppm) & 6.52 \\
\hline
\end{tabular}

Table 1: Chemical, physical and microbial properties of experimental soils and petroleum oil.

\begin{tabular}{|l|l|l|l|l|}
\hline \multirow{2}{*}{ Factor } & \multirow{2}{*}{ Name } & \multicolumn{2}{l|}{ Level } \\
\cline { 5 - 5 } & & 1 & 2 & 3 \\
\hline Aeration & F1 & Aerobic & Anaerobic & ---- \\
\hline Humidity $(\mathrm{ml})$ & F2 & 0.05 & .1 & .5 \\
\hline Glucose $(\mathrm{g})$ & F3 & 0.001 & 0.01 & 0 \\
\hline Bacteria $(\mathrm{ml})$ & F4 & 0 & 0.01 & 0.02 \\
\hline Composting $(\mathrm{g})$ & F5 & 0 & 0.001 & 0.01 \\
\hline Temp. $\left({ }^{\circ} \mathrm{C}\right)$ & F6 & 15 & 25 & 35 \\
\hline Salt $(\mathrm{g})$ & F7 & 0.05 & 0.01 & 0.001 \\
\hline Urea $(\mathrm{g})$ & F8 & 0.05 & 0.01 & 0.001 \\
\hline
\end{tabular}

Table 2: Factors and their levels in the first step of experiment per $\mathrm{g}$ of soil

as only source of carbon for growth of strains in pure cultures. This media was used to test the biodegradation ability of the strains. The GC method was used to determine the biodegradation of petroleum oil by this bacterium in pervious study [16].

\section{Design of experiment (DOE)}

There are a number of environmental and biological parameters which affect a bioremediation process. The DOE technique helps to study many variables simultaneously and most economically. By studying the effects of individual factors on the results, the best combination of factors can be determined. In this work the Taguchi method [17,18] was employed and two sets of experiments were designed. In each set, 8 variables were introduced in which one variable was considered in two levels and others had 3 levels. Table 2 shows the considered parameters and their levels in set 1 . In this set, experiments can be divided in 2 basic categories, the open and sealed containers for aerobic and anaerobic condition. The sealed containers were defined as the nearly anaerobic conditions. The amount of the soil in the container was about 7 gram. However, open containers were supposed to be in the aerobic condition. Therefore, aeration was the only two levels parameter. The other parameters were bacteria, humidity, glucose (as an additional carbon source), compost (as an auxiliary nutrient source), temperature, salt, and urea (as a nitrogen source). By addition of $3 \mathrm{ml}$ phosphate buffer solution per $10 \mathrm{~g}$ of dried soil, the humidity of samples was adjusted.

The second sets of experiments were designed according to the results of the first set. The basic different between two sets of experiments was the aeration condition. In the second set, all experiments carried out in aerobic conditions. Also, in the second set glucose as an initial carbon source was substituted with molasses, as another carbon sources, activated sludge was added to culture as a new parameter and finally all experiments were done in a same temperature. The variables and their levels for the second set of experiments are given in Table 3. Data in table 4 by Taguchi design are shown 18 experiments (runs) for each set, which is known as L-18. These runs are introduced in Table 4. It should be pointed out that each run of introduced experiments of Table 2 and 3 were replicated two times and average percent of oil removal will be reported. The statistical analysis of the data was done by using the Qualitec4 software [17].

\section{Analyses of petroleum hydrocarbon}

The Infra red spectroscopy (IR) method was used to determine the concentration of hydrocarbons in soil samples. Each sample at first was incubated at $60^{\circ} \mathrm{C}$ for $24 \mathrm{~h}$, and then $10 \mathrm{~g}$ of soil was extracted with 20 $\mathrm{ml}$ of $\mathrm{CCl}_{4}$ in an ultrasonic bath for $30 \mathrm{~min}$. The extraction efficiency of this method was higher than $95 \%$. The upper phase was separated and its absorption at $2925 \mathrm{~cm}^{-1}$ was determined by IR (Shimadzu Model). 
Concentrations of hydrocarbon were calculated by calibration curve. Calibration curve was prepared by measurement of IR absorption of extracted phase of contaminated soils samples $(0-0.05 \mathrm{ml}$ crude oil/g of soil) with $\mathrm{CCl}_{4}\left(20 \mathrm{ml} \mathrm{CCl}_{4}\right.$ per $10 \mathrm{~g}$ of sample, and ultrasonic treatment for $30 \mathrm{~min}$.) at $2925 \mathrm{~cm}^{-1}$. The IR absorption of calibration samples has been determined and the relation between absorption and concentration of crude oil was linear between $0-0.05 \mathrm{ml}$ crude oil $/ \mathrm{g}$ soils.

\section{Microcosm preparation}

Since DOE suggested an L-18 array (18 runs) for each set of experiment, 18 soil samples $(10 \mathrm{~g})$ were artificially contaminated with crude oil to a level of $50 \mathrm{ml} \mathrm{kg}^{-1}$ of dried soil. Urea (as nitrogen source), glucose or molasses (as additional carbon source or initiator of bacterial activity), salt $(\mathrm{NaCl})$, humidity and compost for each sample were adjusted according to Tables 3,4 and 5. Then, the prepared bacteria were added to each sample according to DOE. The bacteria were prepared as follows: Each strain separately grown in nutrient broth culture. Then bacteria were centrifuged $(6000 \mathrm{rpm})$ and dissolved by physiologic serum. The resulted solutions were called solutions L, H1 and $\mathrm{H} 2$, and the colony forming units (CFU) of strains per $1 \mathrm{ml}$ of solution was adjusted to $2 \times 10^{7}$. We added the same volume of each solution to soil samples. It means that in all experiments the ratio of solutions was as 1:1:1. Aerobic and anaerobic conditions were applied to samples by opening and closing the caps of containers, respectively.

\begin{tabular}{|l|l|l|l|l|}
\hline \multirow{2}{*}{ Factor } & Name & Level & \\
\cline { 2 - 5 } & & 1 & 2 & 3 \\
\hline Time $($ day $)$ & F1 & 10 & 20 & ---- \\
\hline Salt $(\mathrm{g})$ & F2 & 0.001 & 0.01 & 0.05 \\
\hline Activated sludge $(\mathrm{ml})$ & F3 & 0.02 & 0.01 & 0 \\
\hline Bacteria $(\mathrm{ml})$ & F4 & 0 & 0.01 & 0.02 \\
\hline Composting $(\mathrm{g})$ & F5 & 0.001 & 0.005 & 0 \\
\hline Molasses & F6 & 0.001 & 0.01 & 0 \\
\hline Humidity $(\mathrm{ml})$ & F7 & 0.05 & 0.1 & 0.25 \\
\hline Urea $(\mathrm{g})$ & F8 & 0 & 0.001 & 0.005 \\
\hline
\end{tabular}

Table 3: Factors and their levels in the seconds step of experiments per $\mathrm{g}$ of soil.

\begin{tabular}{|l|l|l|l|l|l|l|l|l|}
\hline F8. & F7 & F6 & F5 & F4 & F3 & F2 & F1 & Run \\
\hline Level & Level & Level & Level & Level & Level & Level & Level & \\
\hline 1 & 1 & 1 & 1 & 1 & 1 & 1 & 1 & 1 \\
\hline 2 & 2 & 2 & 2 & 2 & 2 & 1 & 1 & 2 \\
\hline 3 & 3 & 3 & 3 & 3 & 3 & 1 & 1 & 3 \\
\hline 2 & 2 & 1 & 3 & 3 & 1 & 2 & 1 & 4 \\
\hline 3 & 3 & 2 & 1 & 1 & 2 & 2 & 1 & 5 \\
\hline 1 & 1 & 3 & 2 & 2 & 3 & 2 & 1 & 6 \\
\hline 3 & 1 & 2 & 3 & 2 & 1 & 3 & 1 & 7 \\
\hline 1 & 2 & 3 & 1 & 3 & 2 & 3 & 1 & 8 \\
\hline 2 & 3 & 1 & 2 & 1 & 3 & 3 & 1 & 9 \\
\hline 2 & 3 & 3 & 1 & 2 & 1 & 1 & 2 & 10 \\
\hline 3 & 1 & 1 & 2 & 3 & 2 & 1 & 2 & 11 \\
\hline 1 & 2 & 2 & 3 & 1 & 3 & 1 & 2 & 12 \\
\hline 1 & 3 & 2 & 2 & 3 & 1 & 2 & 2 & 13 \\
\hline 2 & 1 & 3 & 3 & 1 & 2 & 2 & 2 & 14 \\
\hline 3 & 2 & 1 & 1 & 2 & 3 & 2 & 2 & 15 \\
\hline 3 & 2 & 3 & 2 & 1 & 1 & 3 & 2 & 16 \\
\hline 1 & 3 & 1 & 3 & 2 & 2 & 3 & 2 & 17 \\
\hline 2 & 1 & 2 & 1 & 3 & 3 & 3 & 2 & 18 \\
\hline
\end{tabular}

Table 4: L-18 Design of experimental according to Taguchi method for both sets of experiments.

\begin{tabular}{|l|l|l|l|}
\hline No. & IR Absorption & St. Deviation & $\begin{array}{l}\text { Removal } \\
\text { percent(\%) }\end{array}$ \\
\hline 1 & 0.2880 & 0.0 & 47.42 \\
\hline 2 & 0.2905 & 0.5 & 46.86 \\
\hline 3 & 0.2370 & 2.0 & 58.84 \\
\hline 4 & 0.2385 & 1.5 & 58.50 \\
\hline 5 & 0.2725 & 1.5 & 50.90 \\
\hline 6 & 0.2610 & 1.0 & 53.46 \\
\hline 7 & 0.2405 & 0.5 & 58.04 \\
\hline 8 & 0.2740 & 1.0 & 50.56 \\
\hline 9 & 0.2810 & 5.0 & 49.00 \\
\hline 10 & 0.4160 & 1.0 & 18.80 \\
\hline 11 & 0.4590 & 1.5 & 9.08 \\
\hline 12 & 0.4225 & 0.5 & 17.36 \\
\hline 13 & 0.4075 & 0.5 & 20.70 \\
\hline 14 & 0.4000 & 1.0 & 22.38 \\
\hline 15 & 0.4115 & 1.5 & 19.82 \\
\hline 16 & 0.4000 & 1.0 & 22.38 \\
\hline 17 & 0.4420 & 1.0 & 13.00 \\
\hline 18 & 0.4365 & 0.5 & 14.22 \\
\hline $0 . S .^{\text {a }}$ & 0.4460 & 0.0 & 12.10 \\
\hline & & & \\
\hline Blank samp & & & \\
\hline
\end{tabular}

a:Blank sample

Table 5: Average IR absorption and Removal percent (set 1). Experiments were replicated twice.

Finally each sample was placed in a constant temperature environment according to DOE. While time was not a variable in the first set of experiments, all samples were incubated for 10 days. But time had been considered as a variable for the second sets, therefore according to DOE some samples were incubated for 10 days and the others for 20 days. As an important note, some experimental samples used as the blank with contaminated soil without any additives (These blank used for aerobic and anaerobic condition). These samples were incubated at 20 days and $35^{\circ} \mathrm{C}$.

\section{Results and Discussion}

More biodegradation of hydrocarbons in aerobic compared to anaerobic conditions was the highest significant conclusion by Taguchi method. However, this was expected since the isolated bacterium was aerobic, although most interesting result was that the addition of sludge or compost in aerobic or anaerobic have not shown any significant effect on oil removal from soil yet with adding together of other carbon or nitrogen sources, therefore the Pseudomonas has more activity on oil removal compare to sludge or compost inoculation to oil contamination soil.

\section{Experimental Results}

Chemical, physical and microbial properties of used soils, physical plus chemical properties of the crude oil properties are shown in Table 1. Also the primary biochemical assays for Gram negative have shown that all three strain were oxidize positive, catalyses positive, aerobic oxidative and identified as pseudomonas L,H1 and H2. Factors and their levels in the first and second step of experiments per $\mathrm{g}$ of soil are shown in Table 2 and 3. Eighteen experimental designs, according to Taguchi method for both sets of experiments has seen in Table 4.

Tables 5 and 6 represent the average IR absorption, standard deviation and percent oil removal for samples of both sets of experiments 1 and 2, respectively. These samples are introduced by Table 4 . Columns 2 and 3 in Table 5 (and also in Table 6 for the second set of experiments) in fact show the average IR absorption 
and the standard deviation, respectively, according to every couple of replicated runs. The reported percent oil removal was obtained by these average values (column 3 in Tables 7 and 8). Table 7 shows in the first set of experiments the maximum and minimum percents oil removal were obtained for runs 3 with $58.84 \%$ and 11 with $9.08 \%$, respectively. It can be clearly concluded from Table 7 , the percent removal of runs 1-9 (aerobic runs) are significantly more than runs 10-18 (anaerobic runs). It means that aeration is the most effective parameter in bioremediation of oil contaminated soils with used strains. This is an important conclusion which has been obtained with Taguchi method. This conclusion is confirmed by statistical analysis results, given in the next section, and also is in agreement with the literatures $[18,19,26]$. Since the isolated strains were highly aerobic closed containers were not optimum for oil removal. On the other hand it is possible that the respiration of strains might be inhibited by $\mathrm{CO}_{2}$ or toxic volatile intermediate metabolites production. According to Table 8, runs 10 and 1 with $58.38 \%$ and $20.14 \%$ exhibit the maximum and minimum percents oil removal efficiency, respectively. Schaefer et al. [21] reported in the oil-contaminated soil, total petroleum hydrocarbons were significantly affected by respiration and concentration of microbial biomass [20]. Also Mukherji et al. [22], reported the laboratory scale batch studies to test the diesel oil biodegradation ability of isolated strains from Arabian Sea sediments obtained from the vicinity of an oil field, which could utilize diesel oil as the sole source of carbon and energy. They observed 39\% loss of diesel oil over 8 days where $80 \%$ of the loss was due to aliphatic constituents under aerobic conditions [21].

The last row of Tables 5 and 6 belong to the blank samples in both sets of experiments. Oil removal percentage of blank sample was less $13 \%$, in both sets of experiments. Therefore, the intrinsic bioremediation was less than $18 \%$ of results of optimized conditions. In the first set of experiments, runs 1, 5, 9 under aerobic conditions with no addition of bacteria showed values of 45,50 , and $49 \%$ of oil removal, respectively. This could indicate that addition of nutritious together stimulate soil microflora for crude oil biodegradation.

\begin{tabular}{|l|l|l|l|}
\hline No. & IR Absorption & St. Deviation & $\begin{array}{l}\text { Removal } \\
\text { Percent (\%) }\end{array}$ \\
\hline 1 & 0.4100 & 1.0 & 20.14 \\
\hline 2 & 0.2410 & 1.0 & 57.94 \\
\hline 3 & 0.2450 & 1.0 & 57.04 \\
\hline 4 & 0.3680 & 2.0 & 29.54 \\
\hline 5 & 0.3140 & 2.0 & 41.62 \\
\hline 6 & 0.2460 & 2.0 & 56.82 \\
\hline 7 & 0.2710 & 2.0 & 51.24 \\
\hline 8 & 0.2575 & 0.5 & 54.24 \\
\hline 9 & 0.3515 & 1.5 & 33.22 \\
\hline 10 & 0.2390 & 1.0 & 58.38 \\
\hline 11 & 0.3590 & 2.0 & 31.56 \\
\hline 12 & 0.2675 & 0.5 & 52.02 \\
\hline 13 & 0.2685 & 1.5 & 51.78 \\
\hline 14 & 0.2455 & 0.5 & 56.94 \\
\hline 15 & 0.3710 & 2.0 & 28.86 \\
\hline 16 & 0.2600 & 1.0 & 53.70 \\
\hline 17 & 0.3595 & 1.5 & 31.44 \\
\hline 18 & 0.2520 & 0.0 & 55.48 \\
\hline O.S ${ }^{\text {a }}$ & 0.4440 & 0.5 & 12.54 \\
\hline a: Blank sample & & & \\
\hline & & & \\
\hline
\end{tabular}

Table 6: Average IR absorption and Removal percent (set 2). Experiments were replicated twice.

\begin{tabular}{|l|l|l|l|}
\hline Parameter & P1 & P2 & Optimum Condition \\
\hline Aeration F1 & 93.993 & 94.581 & 1 (aeration) \\
\hline Humidity (ml) F2 & 0.999 & 0.949 & 1 \\
\hline Glucose (gr) F3 & 1.452 & 1.404 & 0.01 \\
\hline Bacteria (ml) F4 & 1.112 & 1.062 & 0.02 \\
\hline Composting (gr) F5 & 0.053 & ---- & 0.01 \\
\hline Temp. $\left({ }^{\circ} \mathrm{C}\right)$ F6 & 0.281 & ---- & 35 \\
\hline Salt (gr) F7 & 0.000 & ---- & 0.01 \\
\hline Urea (gr) F8 & 1.206 & 1.157 & 0.01 \\
\hline Other error & 0.904 & 0.847 & ----- \\
\hline Oil removal percent in optimum conditions & & $64.4 \%$ \\
\hline
\end{tabular}

Table 7: The effect percent of each factor (P1), effect percent of more important parameters $(\mathrm{P} 2)$ and optimum conditions for set 1 , determined by the analysis of variance (ANOVA).

\begin{tabular}{|l|l|l|l|}
\hline Parameter & $\mathrm{P} 1$ & $\mathrm{P} 2$ & Optimum Condition \\
\hline Time (day) & 0.583 & 0.583 & 20 \\
\hline Salt $(\mathrm{g})$ & 0.452 & 0.000 & 0.0 \\
\hline Activated sludge $(\mathrm{ml})$ & 0.850 & 0.850 & 0.0 \\
\hline Bacteria $(\mathrm{ml})$ & 89.743 & 89.743 & 0.04 \\
\hline Composting $(\mathrm{g})$ & 0.000 & 0.000 & 0.05 \\
\hline Molasses $(\mathrm{g})$ & 2.562 & 2.546 & 0.1 \\
\hline Humidity $(\mathrm{ml})$ & 2.228 & 2.228 & 1.0 \\
\hline Urea $(\mathrm{g})$ & 2.037 & 2.037 & 0.01 \\
\hline Other error & 1.545 & 1.997 & ---- \\
\hline Oil removal percent in optimum conditions & $68 \%$ \\
\hline
\end{tabular}

Table 8: The effect percent of each factor (P1), effect percent of more important parameters (P2) and optimum conditions for set 2 , determined by the analysis of variance (ANOVA).

\section{Results of Statistical Analysis}

The statistical analysis results of Tables 5 and 6 are given in Tables 7 and 8, respectively, by using the Qualitek 4 software. The contribution percentage of each factor (effect percent) was determined by ANOVA. In addition to this analysis, the optimum conditions could be estimated by the Taguchi method. In Tables 7 and $8, \mathrm{P} 1$ is the effect percent and shows the importance of each parameter in comparison to all parameters, and P2 indicates the effect percent of more important parameters according to statistical analysis when other less important parameters were eliminated with $90 \%$ confidence. It should be noted that, P2 for eliminated parameters was considered as zero. The last columns in Tables 7 and 8 are the estimated optimum conditions according to Taguchi DOE method. Experiments were done in the above mentioned optimum conditions for both set of experiments, and the results has been presented in the last rows of Tables 7 and 8 as oil removal percentage.

According to the results, the maximum percent oil removals were $64.4 \%$ and $68 \%$ for the first set and the second set of experiments, respectively. Another advantage of the Taguchi method is its ability to calculate the percent effect of missed variables or parameters in experiments. It is introduced in Tables 7 and 8 as other errors, and is a criterion of total error due to waive other variables or parameters. Small values of this item represent parameters are selected conveniently. In accordance with Table 7, the effect of aeration on bioremediation is more than $93 \%$ when the sum effect of other parameters is less than $7 \%$. In the other word, the above mentioned result confirms our previous conclusion from Table 5 (results of the first set).

Temperature affects on the physical nature and chemical composition of the oil, rate of hydrocarbon metabolism by 
microorganisms and composition of the microbial community. Therefore petroleum biodegradation is influenced by temperature [18]. The minimum removal in the first set is occurred in temperatures $15^{\circ} \mathrm{C}$. Also percents of oil removal for both 25 and $35^{\circ} \mathrm{C}$ were the same. A temperature of $30^{\circ} \mathrm{C}$ has been reported to be optimum for biodegradation of Bombay High crude oil [4]. At low temperature onset of biodegradation is delayed, because in this case, viscosity of the oil is increased and volatilization of alkanes reduced [22-25]. Rate of hydrocarbon metabolism was improved to a maximum at high temperatures, typically in the range of $30-40^{\circ} \mathrm{C}$, above that the toxicity of hydrocarbons increases [12]. The effect percents (P1) of salt, compost and temperature were $0,0.035$ and 0.281 , respectively. It means that they are the most unimportant parameters, and then P2 is calculated for other parameters when the effect of salt, compost and temperature are eliminated. Finally, Table 7 shows parameters glucose, urea and bacteria have a nearly same impact effect (about 1.1-1.5) on the results. Table 8 shows bacterial inoculation can be considered as the most significant parameter with an effect percent of $89.743 \%$ on aeration conditions. Effect percents of molasses, humidity and urea were 2.562, 2.228 and 2.037, respectively. Therefore they were main important parameters, after bacteria, and introduce nearly similar effect on the results. Also, according to P2 results salt and compost could be eliminated as the most unimportant parameters. It was in accordance with conclusions of the first set of experiments. Finally, effective percent (P1) of time showed that this parameter had a small effect on biodegradation (less than $0.6 \%)$. In addition, main effect analysis shows that there was no significant difference between percents removal for 10 and 20 days. The effect of chemical fertilizers and animal manure on crude oil reduction has been compared and the reduction of the aliphatic and aromatic fractions studied during 8 months by Minai-Tehrani and Herfatmanesh. They observed a higher reduction of crude oil (54\%) in tests containing chemical fertilizers and wood chips [13]. The effect percent (P1) of humidity were relatively significant in both Tables 7 and 8 , which emphasized on role of humidity. The reason could be addressed to the requirement of metabolic activity of bacteria to water. Because the growth of bacteria would be very slow in deficit of humidity conditions. The effect percent (P1) for molasses and glucose could be compared with the other parameters and concluded the additional carbon source has been essential in bioremediation. The effects of biostimulation on total petroleum hydrocarbons have been extensively investigated in controlled conditions and in open field experiments under optimal conditions and addition of biosurfactant [14, 24-26]. It is indicated that growth of bacteria need to initial stimulating. Also, as an economical point, glucose can be substituted with molasses. Since the growth of bacteria will be significantly decreased in high ratio of $\mathrm{C} / \mathrm{N}$, a source of nitrogen should be added in order to modify this ratio in oil contaminated soil. The results of Tables 7 and 8 show urea could be considered as a convenient source of nitrogen in these experiments.

\section{Conclusion}

In this study optimum conditions were obtained for oil removal from contaminated soils by a DOE based on Taguchi method. We could investigate the effect of a number of factors ( 8 factors for each set) simultaneously, with only 18 experiments for each set. Also the relative importance of these factors investigated statistically. It was concluded that the most important parameters are aeration and bacteria. According to statistical analysis of results additional low concentration of carbon source, nitrogen source and humidity are next effective parameters for bioremediation, and the maximum removal obtained during 20 days at $35^{\circ} \mathrm{C}$. Also, it has been shown that addition of activated sludge and compost could not be replaced for the used strains. However, addition of molasses can help to bioremediation of crude oil. Since the isolated bacteria were not salt tolerant, addition of salt inhibit biodegradation in both set of experiments. Finally the optimum conditions were predicted and the results showed that the maximum percent oil removal was about $68 \%$ during 20 days with addition of low concentration of glucose and urea under aerobic condition. Complete degradation might be obtained by longer incubation time.

\section{Acknowledgment}

This work was supported by the research and development office of Isfahan refinery. Authors are grateful to the chemistry department of University of Isfahan for technical assistance in chemical analysis of samples.

\section{References}

1. Ebenhack BW (2006) How do we get there from here? Global Energy Transitions Planning. SPE Annual Technical Conference and Exhibition 24-27 September San Antonio Texas USA.

2. Ward OP (2004) The industrial sustainability of bioremediation processes. J Ind Microbial Biotechnol 31: 1-4.

3. Ward OP, Singh A, Van Hamme J (2003) Accelerated biodegradation of petroleum hydrocarbon waste. J Ind Microbial Biotechnol 30: 260-270.

4. Rahman K, Thahira-Rahman J, Lakshmanaperumalsamy P, Banat IM (2002) Towards efficient crude oil degradation by a mixed bacterial consortium. Biores Technol 85: 257-261.

5. Chaineau CH, Rougeux G, Yepremian C, Oudat J (2005) Effect of nutrient concentration on the biodegradation of crude oil and associated microbia populations in the soil. Soil Biol Biochem 37: 1490-1497.

6. Perfumo A, Bannet IM, Marchanet R, Vezzulli L (2007) Thermally enhanced approches for bioremediation of hydrocarbon contaminated soils. Chemosphere 66: $179-184$

7. Dua M, Singh A, Sethnnathan N, Jobri AK (2002) Biotechnology and bioremediation: successes and limitations. Appl Microbial Biotechnol 59: 143152

8. Boopathy R (2000) Factors limiting bioremediation technologies. Biores Technol 74: 63-67.

9. Molina L, Rodríguez-Vázquez R, Hernández-Velasco M, Vega-Jarquín C Zapata-Pérez O, et al. (2004) Diesel removal from contaminated soils by biostimulation and supplementation with crop residues. Appl Soil Ecol 27: 165175.

10. Ghazali FM, Abdulrahman RNZ, Salleh A, Basri M (2004) Biodegradation of hydrocarbons in soil by microbial consortium. Int Biodeter and biodeg 54 61-67.

11. Semple KT, Reid BJ, Fermor TR (2001) Impact of composting strategies on the treatment of soils contaminated with organic pollutants. Environ Pollut 112 269-283.

12. Huesemann MH, Hausmann TS, Fortman TJ (2002) Microbial factors rathe than bioavailability limit the rate and extent of PAH biodegradation in aged crude oil Contaminated Model Soils. Biorem J 6: 321-336.

13. Minai-Tehrani D, Herfatmanesh A (2007) Biodegradation of aliphatic and aromatic fractions of heavy crude oil-contaminated soil: A Pilot Study. Biorem J 11: 71-76.

14. Prasad KK, Mohan SV, Rao RS, Pati BR, Sarma PN (2005) Laccase production by Pleurotus ostreatus 1804: Optimization of submerged culture conditions by Taguchi DOE methodology. Biochem Eng J 24: 17-26.

15. Raj CB, Quen CHL (2005) Advanced oxidation processes for waste water treatment: optimization of $\mathrm{UV} / \mathrm{H}_{2} \mathrm{O}_{2}$ process through a statistical technique. Chem Eng Sci 60: 5305-5311.

16. Emtiazi G, Shahkarami H, Nahvi I and Mirdamadian SH (2005) Utilization of petroleum hydrocarbons by Pseudomonas sp. and transformed Escherichia coli. Afr J Biotech 4: 172-176.

17. Ranjit KR (1989) Primer on the Taguchi Method, Van Nostrand Reinhold, New 
Citation: Aghamiri SF, Kabiri K, Emtiazi G (2011) A Novel Approach for Optimization of Crude Oil Bioremediation in Soil by the Taguchi Method. J Pet Environ Biotechnol 2:110. doi:10.4172/2157-7463.1000110

York.

18. Ranjit KR (2001) Design of experiments using the Taguchi approach: 16 steps to product and process improvement, Wiley, New York.

19. Mishra S, Sarma PM, Lal B (2004) Crude oil degradation of a recombinant Acinetobacter Baumannnii Strain and its survival in crude oil-contaminated soil microcosm. FEMS Microbiol Lett 325: 323-331.

20. Ouyang W, Liu H, Murigina V, Yu Y, Xiu Z, et al. (2005) Comparision of bioaugmentation and composting for remediation of oily sludge: A field study in China. Proc Biochem 40: 3763-3768.

21. Schaefer M, Petersen SO, Filser J (2005) Effects of Lumbricus terrestris, Allolobophora chlorotica and Eisenia fetida on microbial community dynamics in oil-contaminated soil. Soil Biol Biochem 37: 2065-2076.

22. Mukherji S, Jagadevan S, Mohapatra G, Vijay A (2004) Biodegradation of diesel oil by an Arabian Sea sediment culture isolated from the vicinity of an oil field. Biores Technol 95: 281-286.
23. Olivera NL, Esteves JL (1997) Commendatore, Alkane biodegradation by a microbial community from contaminated sediments in Patagonia, Argentina. Int Biodeter Biodeg 40: 75-79.

24. Hasanshahian M, Emtiazi Giti (2008) Investigation of alkane biodegradation using the microtiter plate method and correlation between biofilm formation, biosurfactant production and crude oil biodegradation. Int Biodete Biodeg 62:170-178

25. Mirdamadian SH, Emtiazi G, Golabiand MH, Ghanavati H (2010) Bacteria isolated from petroleum-contaminated soil. J Pet Environ Biotech 120

26. Rao R S, Kumar C, Prakasham R, Hobbs P J (2008) The Taguchi methodology as a statistical tool for biotechnological applications: A critical appraisal. Biotechnology J 3: 510-523.

27. Soleimani M, Afyuni M, Hajabbasi MA, Nourbakhsh F, Sabzalian MR, et al (2010) Phytoremediation of an aged petroleum contaminated soil using endophyte infected and non-infected grasses. Chemosphere 81: 1084-1090. 